\title{
Potentiation of PBD dimers by lipophilicity manipulation.
}

\author{
Thaïs Cailleau*a, Lauren R. Adams ${ }^{\text {a }}$, Neha Arora ${ }^{\text {a }}$, Gyoung-Dong Kang ${ }^{\text {a }}$, Luke Masterson ${ }^{\text {a }}$, Neki Patel ${ }^{\text {a }}$, \\ John A. Hartley ${ }^{\mathrm{a}}$, Shenlan Mao ${ }^{\mathrm{b}}$, Jay Harper ${ }^{\mathrm{b}}$, Philip W. Howard ${ }^{\mathrm{a}}$. \\ ${ }^{a}$ Spirogen-Medimmune, Queen Mary BioEnterprises Innovation Centre, 42 New road, Whitechapel, London \\ E1 2AX. ${ }^{b}$ Oncology Research, MedImmune, LLC, Gaithersburg, Maryland.

\begin{abstract}
Pyrrolobenzodiazepine (PBD) dimers are highly potent DNA cross linking agents used as warheads in Antibody Drug Conjugates (ADCs) for cancer therapy. We propose to investigate the correlation existing between the lipophilicity of those molecules and their activity (both in vitro and in vivo) as well as any effect observed during conjugation.
\end{abstract}

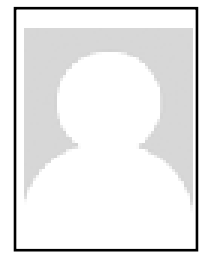

Keywords: ADC, Pyrrolobenzodiazepine, P-gp pump, Tesirine, $N$-Methylpiperazine, Amide coupling, Cathepsin B.

\section{INTRODUCTION}

In recent years, Antibody Drug Conjugates (ADCs) have become established as a platform for the treatment of cancer[1]. The selectivity of monoclonal antibodies, combined with the cytotoxicity of the released warheads, has proved to be an effective combination for targeting both hematological and solid tumors as demonstrated by Adcetris ${ }^{\circledR}$ and Kadcyla ${ }^{\circledR}$. Adcetris consists of Auristatin E analogue (MMAE) linked to the antibody through a lysosomally cleavable dipeptide[2] and inhibits cell division by blocking the polymerisation of tubulin. Kadcyla employs maytansinoid DM1 as warhead, attached to the antibody through a non-cleavable linker[3], and induces mitotic arrest by suppressing microtubule dynamic instability. More recently, Besponsa ${ }^{\circledR}$ and Mylotarg ${ }^{\circledR}$ were approved for the treatment of acute lymphoblastic leukemia (ALL)[4] and acute myeloid leukemia (AML)[5] respectively. These two ADCs use the same calicheamicin warhead, linked to the antibody through a cleavable hydrazone linker, able to bind to the DNA minor groove. This triggers the formation of a diradical species which in turn causes DNA scission and leads to cell apoptosis.

A new highly potent class of ADC warheads, with an alternative mode of action, are the pyrrolobenzodiazepine (PBD) antitumour antibiotics[6]. PBD dimers recognise 5'purine-GATC-pyrimidine DNA sequences and produce nondistorting interstrand crosslinks by binding covalently to guanine[7, 8]. The resulting DNA adducts are persistent and resistant to repair, blocking replication which leads to apoptosis and cell death. There are currently several registered clinical trials with $\mathrm{PBD}$ ADCs using either tesirine SG3249[9] or talirine SG3211 (Fig. (1)) payloads (druglinkers).

Tesirine is the payload used in ADCT's Lonca-T and is involved in phase II trial for patients with relapsed or refractory diffuse large B-cell lymphoma[10]. In the case of tesirine, the warhead is linked to the antibody by a dipeptide$p$-aminobenzyl alcohol (PAB) trigger attached to the N10

XXX-XXX/14 \$58.00+.00 position of the warhead. Seattle Genetics payload talirine however, has the dipeptide trigger directly attached to an anilino handle at the $\mathrm{C} 2$ position of the warhead. Talirine has been investigated in several clinical trials for hematological targets[11, 12].

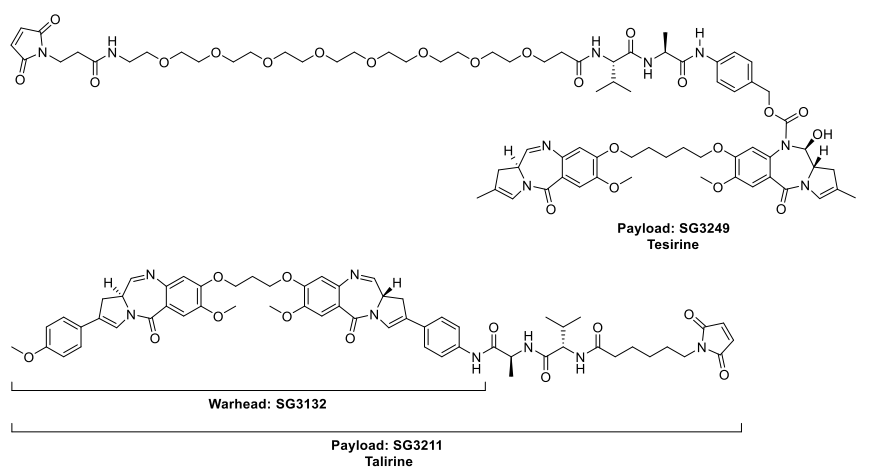

Fig. (1). Structure of clinically investigated PBD payloads.

While Seattle Genetics ADCs display exquisite potency and a high degree of selectivity, the authors highlighted that the poor solubility of the payload led to difficulties during conjugation.

Low aqueous solubility of the payload called for the use of propylene glycol as co-solvent[11]. The low conversion rates and high levels of aggregation observed when conjugating to endogenous hinge cysteines of hiF6 mAb necessitated the synthesis of a modified antibody, introducing engineered cysteines at the 239 position in the heavy chain.

In order to overcome these limitations, we envisaged the synthesis of a more hydrophilic PBD dimer.

\section{MATERIAL AND METHODS.}

Reaction progress was monitored by thin-layer chromatography (TLC) using Merck Kieselgel 60 F254 silica gel, with fluorescent indicator on aluminium plates. Visualisation of TLC was achieved with UV light or iodine 
vapour unless otherwise stated. Flash chromatography was performed using Merck Kieselgel 60 F254 silica gel. Extraction and chromatography solvents were bought and used without further purification from Fisher Scientific, U.K. All chemicals were purchased from Sigma-Aldrich, Strem or VWR.

LC/MS data were obtained using a Shimadzu Nexera series LC/MS with a Shimadzu LC/MS-2020 quadrupole MS, with Electrospray ionisation. Mobile phase A - $0.1 \%$ formic acid in water. Mobile phase B - $0.1 \%$ formic acid in acetonitrile. 3min run: Initial composition was 5\% B held over $0.25 \mathrm{~min}$, then increase from $5 \%$ B to $100 \% \mathrm{~B}$ over a 2 min period. The composition was held for $0.50 \mathrm{~min}$ at $100 \% \mathrm{~B}$, then returned to $5 \% \mathrm{~B}$ in 0.05 minutes and hold there for $0.05 \mathrm{~min}$. Total gradient run time equals $3 \mathrm{~min}$. Flow rate $0.8 \mathrm{~mL} / \mathrm{min}$. Wavelength detection range: 190 to $800 \mathrm{~nm}$. Oven temperature: $50^{\circ} \mathrm{C}$. Column: Waters Acquity UPLC® BEH Shield RP18 $1.7 \mu \mathrm{m} 2.1 \times 50 \mathrm{~mm}$ at $50{ }^{\circ} \mathrm{C}$ fitted with Waters Acquity UPLC ${ }^{\circledR}$ BEH Shield RP18 VanGuard ${ }^{\mathrm{TM}}$ Precolumn, 130A, $1.7 \mu \mathrm{m}, 2.1 \mathrm{~mm}$ x $5 \mathrm{~mm}$

15minute run: Initial composition 5\% B held over 1.25 minutes, then increased from $5 \% \mathrm{~B}$ to $100 \% \mathrm{~B}$ over an 8.75 min period. The composition was held for 2.5 minutes at $100 \% \mathrm{~B}$, then returned to $5 \% \mathrm{~B}$ in 30 seconds and held there for 2 minutes. The total duration of the gradient run was 15.0 minutes. Flow rate was $0.6 \mathrm{~mL} /$ minute Wavelength detection range: 190 to $800 \mathrm{~nm}$. Oven temperature: $50^{\circ} \mathrm{C}$. Column: Waters Acquity UPLC CSH C18, $1.7 \mu, 2.1 \times 100 \mathrm{~mm}$ fitted with Waters Acquity UPLC ${ }^{\circ}$ BEH Shield RP18 VanGuard ${ }^{\text {TM }}$ Pre-column, 130A, $1.7 \mu \mathrm{m}, 2.1 \mathrm{~mm}$ x $5 \mathrm{~mm}$.

UPLC system, or equivalent, consisting of the following, or equivalent:

SRD-3600 solvent rack, 6 degassing Lines; HPG-3400RS PUMP (Thermo Scientific); WPS-3000TFC analytical autosampler (Thermo Scientific); TCC-3000RS column thermostat (Thermo Scientific); DAD-3000RS detector (Thermo Scientific); Q exactive mass detector (Thermo Scientific); Computer operation with $\mathrm{X}$ Calibur and data process with Chromeleon software (Thermo Scientific)

Waters Acquity UPLC CSH C18, 1.7, 2.1 x 150mm column. Acetonitrile, HPLC-MS grade. Water, HPLC-MS grade. Formic acid, HPLC-MS grade. Mobile phase A $0.1 \% \mathrm{v} / \mathrm{v}$ formic acid in water. Mobile phase B $-0.1 \% \mathrm{v} / \mathrm{v}$ formic acid in acetonitrile.

55minute run: Initial composition 25\% B held over 1 minutes, then increased from $25 \%$ B to $75 \%$ B over an 49 min period. The composition, then returned to $25 \% \mathrm{~B}$ was held there for 5 minutes. The total duration of the gradient run was 55.0 minutes. Flow rate was $0.5 \mathrm{~mL} /$ minute Wavelength detection range: $223 \mathrm{~nm}$. Oven temperature: $50^{\circ} \mathrm{C}$.

Any reaction, work up or purification where cytotoxic compounds were handled were conducted in a negatively air pressured glovebox.

\section{EXPERIMENTAL.}

(S)-8-(3-(((S)-2-(4-aminophenyl)-7-methoxy-5,11-dioxo-10((2-(trimethylsilyl)ethoxy)methyl)-5,10,11,11a-tetrahydro$1 H$-benzo[e]pyrrolo[1,2-a][1,4]diazepin-8-yl)oxy)propoxy)7-methoxy-5,11-dioxo-10-((2-

(trimethylsilyl)ethoxy)methyl)-5,10,11,11a-tetrahydro- $1 \mathrm{H}$ benzo[e]pyrrolo[1,2-a][1,4]diazepin-2-yl

trifluoromethanesulfonate (2).

$\mathrm{Pd}\left(\mathrm{PPh}_{3}\right)_{4}$ (310 mg, $0.26 \mathrm{mmol}$ ) was added to a stirred mixture of the bis-enol triflate $\mathbf{1}(15 \mathrm{~g}, 13.4 \mathrm{mmol})$, boronic ester $(2.64 \mathrm{~g}, 12 \mathrm{mmol})$ and $\mathrm{Na}_{2} \mathrm{CO}_{3}(6.54 \mathrm{~g}, 61.7 \mathrm{mmol})$ in a 2:1:1 mixture of toluene/MeOH/ $\mathrm{H}_{2} \mathrm{O}(300 \mathrm{~mL})$. The reaction mixture was allowed to stir at $30^{\circ} \mathrm{C}$ under a nitrogen atmosphere for $16 \mathrm{~h}$ after which time all the boronic ester has consumed. The reaction mixture was then evaporated to dryness before the residue was taken up in $\mathrm{CH}_{2} \mathrm{Cl}_{2}(250 \mathrm{~mL})$ and washed with $\mathrm{H}_{2} \mathrm{O}(2 \times 150 \mathrm{~mL})$, brine $(150 \mathrm{~mL})$, dried $\left(\mathrm{MgSO}_{4}\right)$, filtered and evaporated under reduced pressure to provide the crude product. Purification by flash chromatography (gradient elution: 80:20 v/v Hexane/EtOAc to $60: 40 \mathrm{v} / \mathrm{v}$ Hexane/EtOAc) afforded product 2 as a yellow foam $(6.38 \mathrm{~g}, 45 \%)$.

$\mathrm{LC}_{\mathrm{MS}}\left(\mathrm{Bmin}_{\mathrm{min}} 1.87 \mathrm{~min}(\mathrm{ES}+) \mathrm{m} / \mathrm{z}=1060.35[M+\mathrm{H}]^{+}\right.$.

(S)-2-(4-aminophenyl)-7-methoxy-8-(3-(((S)-7-methoxy-2(4-(4-methylpiperazin-1-yl)phenyl)-5,11-dioxo-10-((2(trimethylsilyl)ethoxy)methyl)-5,10,11,11a-tetrahydro- $1 H$ benzo[e]pyrrolo[1,2-a][1,4]diazepin-8-yl)oxy)propoxy)-10((2-(trimethylsilyl)ethoxy)methyl)-1,11a-dihydro-5Hbenzo[e]pyrrolo[1,2-a][1,4]diazepine-5,11(10H)-dione (3).

$\mathrm{Pd}\left(\mathrm{PPh}_{3}\right)_{4}(87 \mathrm{mg}, 0.075 \mathrm{mmol})$ was added to a stirred mixture of the aniline-triflate $2(4 \mathrm{~g}, 3.77 \mathrm{mmol})$, boronic ester $(1.13 \mathrm{~g}, 3.77 \mathrm{mmol})$ and triethylamine $(4.23 \mathrm{~mL}, 30.1$ $\mathrm{mmol})$ in a $2: 1: 1$ mixture of toluene/ $\mathrm{MeOH} / \mathrm{H}_{2} \mathrm{O}(10 \mathrm{~mL})$. The reaction mixture was microwaved at $85^{\circ} \mathrm{C}$ for $15 \mathrm{~min}$. The resulting mixture was taken up in $\mathrm{CH}_{2} \mathrm{Cl}_{2}(75 \mathrm{~mL})$ and washed with $\mathrm{H}_{2} \mathrm{O}(2 \times 50 \mathrm{~mL})$, brine $(50 \mathrm{~mL})$, dried $\left(\mathrm{MgSO}_{4}\right)$, filtered and evaporated under reduced pressure to provide the crude product. Purification by flash chromatography (gradient elution: 80:20 v/v Hexane/EtOAc to 40:60 v/v Hexane/EtOAc) afforded product 3 as a yellow foam $(3.107 \mathrm{~g}, 75 \%)$.

$\mathrm{LC} \mathrm{MS}_{(3 \min )} 1.39 \mathrm{~min}(\mathrm{ES}+) \mathrm{m} / z=1087.20[\mathrm{M}+\mathrm{H}]^{+}$.

(S)-2-(4-aminophenyl)-7-methoxy-8-(3-(((S)-7-methoxy-2(4-(4-methylpiperazin-1-yl)phenyl)-5-oxo-5,11a-dihydro1H-benzo[e]pyrrolo[1,2-a][1,4]diazepin-8-yl)oxy)propoxy)1,11a-dihydro-5H-benzo[e]pyrrolo[1,2-a][1,4]diazepin-5-one (SG3312).

A solution of Super-Hydride ${ }^{\circledR}(220 \mu \mathrm{L}, 1 \mathrm{M}$ in THF) was added dropwise to a solution of SEM-dilactam 3 (104 mg, $0.095 \mathrm{mmol})$ in dry $\mathrm{CH}_{2} \mathrm{Cl}_{2}(5 \mathrm{~mL})$ at $-78^{\circ} \mathrm{C}$ under an argon atmosphere. After 40 minutes, an aliquot was quenched with water for LC/MS analysis, which revealed that the reaction was complete. Water $(20 \mathrm{~mL})$ was added to the reaction mixture and the cold bath was removed. The organic layer was extracted with $\mathrm{CH}_{2} \mathrm{Cl}_{2}(3 \times 25 \mathrm{~mL})$ and the combined organics were washed with brine $(50 \mathrm{~mL})$, dried with $\mathrm{MgSO}_{4}$, filtered and the solvent removed by rotary 
evaporation under reduced pressure. The crude product was dissolved in 1:1 mixture of $\mathrm{H}_{2} \mathrm{O} / \mathrm{CH}_{3} \mathrm{CN}(10 \mathrm{~mL})+0.1 \%$ volume of formic acid and the mixture was left to stir at room temperature for $1 \mathrm{~h}$. The solution was neutralised to $\mathrm{pH}=7$ with a saturated solution of $\mathrm{NaHCO}_{3(\mathrm{aq})}$ and the suspension was filtered through a sintered funnel. The solid was recovered from the sintered funnel by dissolving in a 1:4 solution of $\mathrm{MeOH} / \mathrm{CHCl}_{3}(50 \mathrm{~mL})$ before the solvents were removed in vacuo. Purification by silica gel column chromatography (isolera, $\mathrm{CHCl}_{3} /\left(\mathrm{CHCl}_{3}+10 \% \mathrm{MeOH}\right)$ 98:2 to 20:80) afforded SG3312 as a yellow solid (40.1 mg, $43 \%)$.

$\mathrm{LC} \mathrm{MS}_{(3 \mathrm{~min})} 1.00 \mathrm{~min}(\mathrm{ES}+) \mathrm{m} / z=397.80[M+2 \mathrm{H}]^{2+}$; $\mathrm{LC} \mathrm{MS}_{(15 \mathrm{~min})} 3.75 \mathrm{~min}(\mathrm{ES}+) \mathrm{m} / z=794.30[\mathrm{M}+\mathrm{H}]^{+}$

Allyl $\quad((S)-1-(((S)-1-((4-)(S)-7-m e t h o x y-8-(3-)((S)-7-$ methoxy-2-(4-(4-methylpiperazin-1-yl)phenyl)-5,11-dioxo10-((2-(trimethylsilyl)ethoxy)methyl)-5,10,11,11atetrahydro-1H-benzo[e]pyrrolo[1,2-a][1,4]diazepin-8yl)oxy)propoxy)-5,11-dioxo-10-((2-

(trimethylsilyl)ethoxy)methyl)-5,10,11,11a-tetrahydro-1Hbenzo[e]pyrrolo[1,2-a][1,4]diazepin-2-yl)phenyl)amino)-1oxopropan-2-yl)amino)-3-methyl-1-oxobutan-2-

yl)carbamate (4)

To a solution of $\mathbf{3}(100 \mathrm{mg}, 0.092 \mathrm{mmol})$ in dry $\mathrm{CH}_{2} \mathrm{Cl}_{2}(10$ $\mathrm{mL}$ ) was added the protected peptide $(24 \mathrm{mg}, 0.096 \mathrm{mmol})$ and EEDQ (23 mg, $0.096 \mathrm{mmol})$. The mixture was stirred at room temperature until completion (16h). The reaction mixture was then washed with $\mathrm{H}_{2} \mathrm{O}(2 \times 50 \mathrm{~mL})$, brine $(50$ $\mathrm{mL})$, dried $\left(\mathrm{MgSO}_{4}\right)$, filtered and evaporated under reduced pressure to provide the crude product. Purification by flash chromatography (gradient elution: $100 \% \mathrm{CHCl}_{3}$ to $95 / 5$ $\left.\mathrm{CHCl}_{3} / \mathrm{MeOH}\right)$ afforded product 4 as a yellow foam $(88 \mathrm{mg}$, $71 \%)$.

$\mathrm{LC} / \mathrm{MS}_{(3 \min )} 1.47 \mathrm{~min}(\mathrm{ES}+) \mathrm{m} / z=1341.60[\mathrm{M}+\mathrm{H}]^{+}$.

(9H-Fluoren-9-yl)methyl $((S)-1-(((S)-1-((4-((S)-7-m e t h o x y-$ 8-(3-(((S)-7-methoxy-2-(4-(4-methylpiperazin-1-yl)phenyl)5,11-dioxo-10-((2-(trimethylsilyl)ethoxy)methyl)-

5,10,11,11a-tetrahydro- $1 \mathrm{H}$-benzo[e]pyrrolo[1,2-

a][1,4]diazepin-8-yl)oxy)propoxy)-5,11-dioxo-10-((2-

(trimethylsilyl)ethoxy)methyl)-5,10,11,11a-tetrahydro- $1 \mathrm{H}$ -

benzo[e]pyrrolo[1,2-a][1,4]diazepin-2-yl)phenyl)amino)-1-

oxopropan-2-yl)amino)-3-methyl-1-oxobutan-2-

yl)carbamate (7).

To a solution of aniline $3(500 \mathrm{mg}, 0.459 \mathrm{mmol})$ in dry $\mathrm{CH}_{2} \mathrm{Cl}_{2}(20 \mathrm{~mL})$ was added Fmoc-Val-Ala-OH $(188 \mathrm{mg}$, $0.459 \mathrm{mmol})$ and HATU (170 $\mathrm{mg}, 0.459 \mathrm{mmol})$. The mixture was stirred at room temperature until completion $(\approx 1 \mathrm{~h})$. The reaction mixture was diluted with $\mathrm{CH}_{2} \mathrm{Cl}_{2}(50$ $\mathrm{mL})$, then washed with $\mathrm{H}_{2} \mathrm{O}(2 \times 50 \mathrm{~mL})$, brine $(50 \mathrm{~mL})$, dried $\left(\mathrm{MgSO}_{4}\right)$, filtered and evaporated under reduced pressure to provide the crude product. Purification by flash chromatography (gradient elution: $100 \% \mathrm{CHCl}_{3}$ to $97 / 3$ $\mathrm{CHCl}_{3} / \mathrm{MeOH}$ ) afforded product 7 as a yellow foam (483 $\mathrm{mg}, 71 \%$ yield).

LC/MS $(60 \min ) 41.47 \mathrm{~min}(\mathrm{ES}+) \mathrm{m} / z .1479 .70[M+\mathrm{H}]^{+}$.

UPLC r.t. $=41.47 \mathrm{~min}$.
(9H-fluoren-9-yl)methyl ((S)-1-(((S)-1-((4- $((S)$-7-methoxy-8(3-(((S)-7-methoxy-2-(4-(4-methylpiperazin-1-yl)phenyl)-5oxo-5,11a-dihydro-1 $H$-pyrrolo[2,1-c][1,4]benzodiazepin-8yl)oxy)propoxy)-5-oxo-5,11a-dihydro- $1 H$-pyrrolo[2,1c][1,4]benzodiazepin-2-yl)phenyl)amino)-1-oxopropan-2yl)amino)-3-methyl-1-oxobutan-2-yl)carbamate (8).

A solution of Super-Hydride ${ }^{\circledR}(236 \mu \mathrm{L}, 1 \mathrm{M}$ in THF) was added dropwise to a solution of SEM-dilactam 7 (140 mg, $0.095 \mathrm{mmol})$ in dry $\mathrm{CH}_{2} \mathrm{Cl}_{2}(5 \mathrm{~mL})$ at $-78^{\circ} \mathrm{C}$ under an argon atmosphere. After 40 minutes, an aliquot was quenched with water for LC/MS analysis, which revealed that the reaction was complete. Water $(20 \mathrm{~mL})$ was added to the reaction mixture and the cold bath was removed. The organic layer was extracted with $\mathrm{CH}_{2} \mathrm{Cl}_{2}(3 \times 25 \mathrm{~mL})$ and the combined organics were washed with brine $(50 \mathrm{~mL})$, dried with $\mathrm{MgSO}_{4}$, filtered and the solvent removed by rotary evaporation under reduced pressure. The crude product was dissolved in $1: 1$ mixture of $\mathrm{H}_{2} \mathrm{O} / \mathrm{CH}_{3} \mathrm{CN}(10 \mathrm{~mL})+0.1 \%$ volume of formic acid and the mixture was left to stir at room temperature for $1 \mathrm{~h}$. The solution was neutralised to $\mathrm{pH}=7$ with a saturated solution of $\mathrm{NaHCO}_{3(\mathrm{aq})}$ and the suspension was filtered through a sintered funnel. The solid was recovered from the sintered funnel by dissolving in a 1:4 solution of $\mathrm{MeOH} / \mathrm{CHCl}_{3}(50 \mathrm{~mL})$ before the solvents were removed in vacuo. Purification by silica gel column chromatography (isolera, $\mathrm{CHCl}_{3} /\left(\mathrm{CHCl}_{3}+10 \% \mathrm{MeOH}\right) 98: 2$ to $40: 60)$ afforded 8 as a yellow solid (51 $\mathrm{mg}, 45 \%)$. $\mathrm{LC} \mathrm{MS}_{(3 \min )} 1.32 \mathrm{~min}(\mathrm{ES}+) \mathrm{m} / z=594.05[M+2 \mathrm{H}]^{2+.}$.

$(S)-2$-amino- $N-((S)-1-((4-((\mathrm{S})-7-m e t h o x y-8-(3-)((R)-7-$ methoxy-2-(4-(4-methylpiperazin-1-yl)phenyl)-5-oxo-5,11adihydro-1H-pyrrolo[2,1-c][1,4]benzodiazepin-8-

yl)oxy)propoxy)-5-oxo-5,11a-dihydro- $1 H$-pyrrolo[2,1c][1,4]benzodiazepin-2-yl)phenyl)amino)-1-oxopropan-2yl)-3-methylbutanamide (9).

Excess piperidine was added $(20 \mu \mathrm{L})$ to a solution of PBD 8 $(88 \mathrm{mg}, 0.07 \mathrm{mmol})$ in DMF $(2 \mathrm{~mL})$. The mixture was allowed to stir at room temperature for $20 \mathrm{~min}$, at which point the reaction had gone to completion (as monitored by LC/MS). The reaction mixture was diluted with $\mathrm{CH}_{2} \mathrm{Cl}_{2}$ (30 $\mathrm{mL})$ and the organic phase was washed with $\mathrm{H}_{2} \mathrm{O}(2 \times 30$ $\mathrm{mL}$ ) until complete piperidine removal. The organic phase was dried over $\mathrm{MgSO}_{4}$, filtered and excess solvent removed by rotary evaporation under reduced pressure to afford crude product 9 which was used as such in the next step.

$\mathrm{LC} \mathrm{MS}_{(3 \min )} 1.03 \mathrm{~min}(\mathrm{ES}+) \mathrm{m} / z=483.00[M+2 \mathrm{H}]^{2+.}$.

6-(2,5-Dioxo-2,5-dihydro-1H-pyrrol-1-yl)- $N-((S)-1-(((S)-1-$ ((4-)((S)-7-methoxy-8-(3-(((S)-7-methoxy-2-(4-(4-

methylpiperazin-1-yl)phenyl)-5-oxo-5,11a-dihydro- $1 \mathrm{H}$ pyrrolo[2,1-c][1,4]benzodiazepin-8-yl)oxy)propoxy)-5-oxo5,11a-dihydro- $1 H$-pyrrolo[2,1-c][1,4]benzodiazepin-2yl)phenyl)amino)-1-oxopropan-2-yl)amino)-3-methyl-1oxobutan-2-yl)hexanamide (SG3259).

EDCI hydrochloride (14 $\mathrm{mg}, 0.07 \mathrm{mmol})$ and 6maleimidohexanoic acid $(15 \mathrm{mg}, 0.07 \mathrm{mmol})$ were added to a solution of 9 (crude) in dry $\mathrm{CH}_{2} \mathrm{Cl}_{2}(10 \mathrm{~mL})$ under an argon atmosphere. Stirring was maintained until the reaction was 
complete (16h). The reaction was diluted with $\mathrm{CH}_{2} \mathrm{Cl}_{2}(30$ $\mathrm{mL})$ and the organic phase was washed with $\mathrm{H}_{2} \mathrm{O}(2 \times 30$ $\mathrm{mL}$ ) and brine before being dried over $\mathrm{MgSO}_{4}$, filtered and excess solvent removed by rotary evaporation under reduced pressure by rotary evaporation under reduced pressure. The product was purified by careful silica gel chromatography (isolera, $\mathrm{CHCl}_{3} / \mathrm{MeOH}$ 98:2 to 80:20) followed by reverse phase HPLC to remove shouldering impurities. Product SG3259 was isolated in $26 \%$ yield over two steps $(22.6 \mathrm{mg})$.

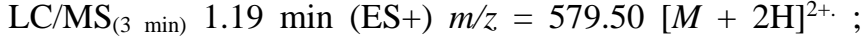
$\mathrm{LC} \mathrm{MS}_{(15 \mathrm{~min})} 5.68 \mathrm{~min}(\mathrm{ES}+) \mathrm{m} / \mathrm{z}=579.50[M+2 \mathrm{H}]^{2+}$.

(9H-fluoren-9-yl)methyl $((S)-1-(((R)-1-((4-((S)-7-m e t h o x y-$ 8-(3-(((S)-7-methoxy-2-(4-(4-methylpiperazin-1-yl)phenyl)5,11-dioxo-10-((2-(trimethylsilyl)ethoxy)methyl)-

5,10,11,11a-tetrahydro- $1 H$-benzo[e]pyrrolo[1,2a][1,4]diazepin-8-yl)oxy)propoxy)-5,11-dioxo-10-((2(trimethylsilyl)ethoxy)methyl)-5,10,11,11a-tetrahydro- $1 \mathrm{H}$ benzo[e]pyrrolo[1,2-a][1,4]diazepin-2-yl)phenyl)amino)-1oxopropan-2-yl)amino)-3-methyl-1-oxobutan-2-

yl)carbamate (10)

To a solution of aniline $3(500 \mathrm{mg}, 0.459 \mathrm{mmol})$ in dry $\mathrm{CH}_{2} \mathrm{Cl}_{2}(20 \mathrm{~mL})$ was added Fmoc-Val-(D)-Ala-OH (188 mg, $0.459 \mathrm{mmol})$ and HATU $(170 \mathrm{mg}, 0.459 \mathrm{mmol})$. The mixture was stirred at room temperature until completion $\left(\approx 1\right.$ h). The reaction mixture was diluted with $\mathrm{CH}_{2} \mathrm{Cl}_{2}(50$ $\mathrm{mL})$, then washed with $\mathrm{H}_{2} \mathrm{O}(2 \times 50 \mathrm{~mL})$, brine $(50 \mathrm{~mL})$, dried $\left(\mathrm{MgSO}_{4}\right)$, filtered and evaporated under reduced pressure to provide the crude product. Purification by flash chromatography (gradient elution: $100 \% \mathrm{CHCl}_{3}$ to $97 / 3$ $\mathrm{CHCl}_{3} / \mathrm{MeOH}$ ) afforded product $\mathbf{1 0}$ as a yellow foam (325 $\mathrm{mg}, 48 \%$ yield).

$\mathrm{LC} \mathrm{MS}_{(60 \mathrm{~min})} 40.77 \mathrm{~min}(\mathrm{ES}+) \mathrm{m} / z 1479.70[M+\mathrm{H}]^{+}$. UPLC r.t. $=40.77$.

(9H-fluoren-9-yl)methyl $\quad((S)-1-(((R)-1-((4-((S)-7-m e t h o x y-$ 8-(3-(((S)-7-methoxy-2-(4-(4-methylpiperazin-1-yl)phenyl)5-oxo-5,11a-dihydro-1H-benzo[e]pyrrolo[1,2-

a][1,4]diazepin-8-yl)oxy)propoxy)-5-oxo-5,11a-dihydro- $1 H$ benzo[e]pyrrolo[1,2-a][1,4]diazepin-2-yl)phenyl)amino)-1oxopropan-2-yl)amino)-3-methyl-1-oxobutan-2-

yl)carbamate (11).

A solution of Super-Hydride ${ }^{\circledR}(0.55 \mathrm{~mL}, 1 \mathrm{M}$ in THF) was added dropwise to a solution of SEM dilactam $10(325 \mathrm{mg}$, $0.218 \mathrm{mmol})$ in THF $(5 \mathrm{~mL})$ at $-78^{\circ} \mathrm{C}$ under an argon atmosphere. The addition was completed over 5 minutes in order to maintain the internal temperature of the reaction mixture constant. After 20 minutes, an aliquot was quenched with water for LC/MS analysis, which revealed that the reaction was complete. Water $(20 \mathrm{~mL})$ was added to the reaction mixture and the cold bath was removed. The organic layer was extracted with EtOAc ( $3 \times 30 \mathrm{~mL})$ and the combined organics were washed with brine $(50 \mathrm{~mL})$, dried with $\mathrm{MgSO}_{4}$, filtered and the solvent removed by rotary evaporation under reduced pressure. The crude product was dissolved in $\mathrm{MeOH}(6 \mathrm{~mL}), \mathrm{CH}_{2} \mathrm{Cl}_{2}(3 \mathrm{~mL})$, water $(1 \mathrm{~mL})$ and enough silica gel to form a thick stirring suspension. After 5 days, the suspension was filtered through a sintered funnel and washed with $\mathrm{CH}_{2} \mathrm{Cl}_{2} / \mathrm{MeOH}(9: 1)(100 \mathrm{~mL})$ until the elution of the product was complete. The organic layer was washed with brine $(2 \times 50 \mathrm{~mL})$, dried with $\mathrm{MgSO}_{4}$, filtered and the solvent removed by rotary evaporation under reduced pressure. Purification by silica gel column chromatography $\left(100 \% \quad \mathrm{CHCl}_{3}\right.$ to $\left.9: 1 \quad \mathrm{CHCl}_{3} / \mathrm{MeOH}\right)$ afforded the product $\mathbf{1 1}$ as a yellow solid $(216.9 \mathrm{mg}, 86 \%)$. $\mathrm{LC} \mathrm{MS}_{(3 \min )} 1.31 \mathrm{~min}(\mathrm{ES}+) \mathrm{m} / z=594.00[\mathrm{M}+2 \mathrm{H}]^{2+.}$.

(S)-2-amino- $N-((R)-1-((4-((S)-7-m e t h o x y-8-(3-(() S)-7-$ methoxy-2-(4-(4-methylpiperazin-1-yl)phenyl)-5-oxo-5,11adihydro- $1 H$-benzo[e]pyrrolo[1,2-a][1,4]diazepin-8-

yl)oxy)propoxy)-5-oxo-5,11a-dihydro- $1 H$ -

benzo[e]pyrrolo[1,2-a][1,4]diazepin-2-yl)phenyl)amino)-1oxopropan-2-yl)-3-methylbutanamide (12).

Excess piperidine was added $(50 \mu \mathrm{L})$ to a solution of PBD 11 (215 mg, $0.181 \mathrm{mmol})$ in DMF $(1.5 \mathrm{~mL})$. The mixture was allowed to stir at room temperature for $20 \mathrm{~min}$, at which point the reaction had gone to completion (as monitored by LC/MS). The reaction mixture was diluted with $\mathrm{CH}_{2} \mathrm{Cl}_{2}$ (30 $\mathrm{mL})$ and the organic phase was washed with $\mathrm{H}_{2} \mathrm{O}(2 \times 30$ $\mathrm{mL}$ ) until complete piperidine removal. The organic phase was dried over $\mathrm{MgSO}_{4}$, filtered and excess solvent removed by rotary evaporation under reduced pressure to afford crude product 12 which was used as such in the next step.

$\mathrm{LC} \mathrm{MS}_{(3 \mathrm{~min})} 1.02 \mathrm{~min}(\mathrm{ES}+) \mathrm{m} / \mathrm{z}=483.00[\mathrm{M}+2 \mathrm{H}]^{2+.}$.

6-(2,5-dioxo-2,5-dihydro-1H-pyrrol-1-yl)-N- $((S)-1-(((R)-1-$ ((4-)((S)-7-methoxy-8-(3-)((S)-7-methoxy-2-(4-(4methylpiperazin-1-yl)phenyl)-5-oxo-5,11a-dihydro- $1 H$ benzo[e]pyrrolo[1,2-a][1,4]diazepin-8-yl)oxy)propoxy)-5oxo-5,11a-dihydro-1 $H$-benzo[e]pyrrolo[1,2-a][1,4]diazepin2-yl)phenyl)amino)-1-oxopropan-2-yl)amino)-3-methyl-1oxobutan-2-yl)hexanamide (SG3664).

EDCI hydrochloride (38 $\mathrm{mg}, 0.199 \mathrm{mmol}$ ) and 6maleimidohexanoic acid (42 $\mathrm{mg}, 0.199 \mathrm{mmol}$ ) were added to a solution of $\mathbf{1 2}$ (crude) in dry $\mathrm{CH}_{2} \mathrm{Cl}_{2}(3 \mathrm{~mL})$ under an argon atmosphere. Stirring was maintained until the reaction was complete (16h). The reaction was diluted with $\mathrm{CH}_{2} \mathrm{Cl}_{2}(30$ $\mathrm{mL})$ and the organic phase was washed with $\mathrm{H}_{2} \mathrm{O}(2 \times 30$ $\mathrm{mL}$ ) and brine before being dried over $\mathrm{MgSO}_{4}$, filtered and excess solvent removed by rotary evaporation under reduced pressure by rotary evaporation under reduced pressure. The product was purified by reverse phase HPLC to remove shouldering impurities. Product SG3664 was isolated in 27\% yield over two steps (56 mg).

$\mathrm{LC} \mathrm{MS}_{(3 \mathrm{~min})} 1.18 \mathrm{~min}(\mathrm{ES}+) \mathrm{m} / z=579.5[M+2 \mathrm{H}]^{2+.}$; $\mathrm{LC} \mathrm{MS}_{(15 \mathrm{~min})} 5.71 \mathrm{~min}(\mathrm{ES}+) \mathrm{m} / z=579.50[M+2 \mathrm{H}]^{2+}$.

\section{RESULTS AND DISCUSSION}

\subsection{Design of a hydrophilic PBD.}

The aim of our design was to retain the potency exhibited by talirine (SG3211) whilst improving the hydrophilicity of the payload. A simple but efficient way of modifying the physicochemical properties of a PBD is to modify the substituents at the $\mathrm{C} 2$ positions. In our case, one of the $\mathrm{C} 2$ positions is predetermined so as to provide a synthetic handle for linker attachment. Our attention therefore focused 
on modifying the second $\mathrm{C} 2$ position. It was known that the presence of an aromatic ring was essential to retain potency, therefore we focused our efforts on optimising the ring substituents. It was hypothesised that an ionisable group (with the ability to form a salt) would offset the lipophilic character of the aromatic group and greatly improve the water solubility of the payload. Using an advanced chemical editor [13] to calculate lipophilicity values, we compared the distribution coefficient ( $\log \mathrm{D})$ at $\mathrm{pH}=7.4$ of various $\mathrm{C} 2$ tertiary amines (Table 1).

Table 1: pKa and lipophilicity values for the payload bearing different substituents at the $\mathrm{C} 2$ position.

\begin{tabular}{|l|c|c|c|}
\hline $\mathbf{n K a}$ & - & 4.84 & 7.89 \\
\hline $\operatorname{cLog~D}(\mathbf{p H = 7 . 4 )}$ & 4.71 & 4.97 & 4.21 \\
\hline
\end{tabular}

The addition of a $N$-methyl-piperazinyl group allowed for the distribution coefficient to significantly drop by $0.5 \mathrm{log}$. With a pKa of 7.89 , most of the tertiary amine will be protonated during conjugation in aqueous PBS buffer $(\mathrm{pH}=7.4)$, increasing its propensity to solubilise in aqueous solutions.

As previously used for SG3211, the payload was synthesised to include the protease cleavable valine-alanine dipeptide trigger[14], known to be stable in circulation, but cleaved within the target cell. We chose to build the linker in several steps, adding the trigger first. The valine amine would provide a handle for attaching various spacers, enabling us to access a wide library of payloads from just one intermediate (6).

\subsection{Discussion over the synthetic route.}

The warhead SG3312 and corresponding payload SG3259 of the newly designed compound were synthesised following a linear route. The starting point for the synthesis was the versatile bis-triflate intermediate $\mathbf{1}$ which had previously been synthesised on kilogram scale in eleven steps[15]. Two successive Suzuki couplings provided access to a large library of unsymmetrically substituted C2-aryl PBD dimers.

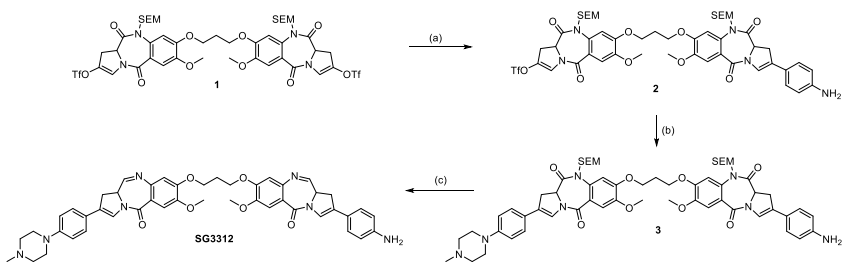

Scheme 1. Synthesis of SG3312 warhead: (a) 4Aminophenylboronic acid pinacol ester, $\mathrm{Pd}\left(\mathrm{PPh}_{3}\right)_{4}$, $\mathrm{NaHCO}_{3}$, Toluene, $\mathrm{MeOH}, \mathrm{H}_{2} \mathrm{O}$; (b) 4-(4-methylpiperazin-1yl)phenylboronic acid pinacol ester, $\mathrm{Pd}\left(\mathrm{PPh}_{3}\right)_{4}$, Triethylamine, Toluene, $\mathrm{MeOH}, \mathrm{H}_{2} \mathrm{O}$; (c) Super-Hydride®, $\mathrm{CH}_{2} \mathrm{Cl}_{2}$ then $1: 1 \mathrm{CH}_{3} \mathrm{CN} / \mathrm{H}_{2} \mathrm{O}+0.1 \%$ Formic acid.

The first step of the synthesis was the installation of the aniline handle for subsequent linker attachment. This was achieved by breaking the symmetry of the molecule by coupling only one equivalent of anilino-boronic ester onto the bis-triflate. It is noteworthy that this is a statistical reaction and any unreacted bis-triflate can easily be recovered during purification and recycled. Subsequent Suzuki coupling with 4-(4-methylpiperazin-1yl)phenylboronic acid, pinacol ester gave intermediate $\mathbf{3}$ in $75 \%$ yield.

At this stage, having completed both Suzuki couplings, it was possible to prepare either the warhead bis-imine (SG3312) by selectively reducing the dilactam and deprotecting the resulting carbinolamines (Scheme 1), or to prepare payload SG3259 for antibody drug conjugation (Scheme 2).

To synthesise the warhead, selective reduction of the SEMdilactam was achieved using our standard conditions: SuperHydride ${ }^{\circledR}$ at $-78^{\circ} \mathrm{C}[15]$. The protected hemiaminal was not isolated and traditional SEM-deprotection conditions, stirring the reduced intermediate with silica gel in a mixture of $\mathrm{CH}_{2} \mathrm{Cl}_{2} / \mathrm{MeOH} / \mathrm{H}_{2} \mathrm{O}$ (6:4:1), should have provided full conversion to the corresponding bis-imine. Unfortunately, in our case, after 6 days of stirring, the isolated product still contained $8 \%$ of protected SEM intermediate.

Further studies established that mild acidic conditions such as treating the hemiaminal with a mixture of $\mathrm{CH}_{3} \mathrm{CN} / \mathrm{H}_{2} \mathrm{O}$ $(1: 1)+0.1 \%$ formic acid for $1 \mathrm{~h}$ at room temperature afforded the desired product, with no remaining trace of the SEM protected intermediate or signs of aromatisation of the $\mathrm{C}$ ring. These new and improved conditions not only significantly decreased the reaction time but also allowed for a simplified work up as the crude material can be recovered by filtration. Using this new set of deprotection conditions, pure warhead SG3312 was isolated in $43 \%$ yield.

The payload was synthesised in an additional four steps starting from SEM-dilactam 3 (Scheme 2). The Val-Ala dipeptide trigger was installed by coupling a protected dipeptide to the aniline.

Our initial route involved the use of Alloc-Val-Ala-OH as the dipeptide and coupling to lactam 3 with EEDQ afforded the desired product in $71 \%$ yield. Subsequent reduction/deprotection gave $\mathbf{5}$ in good yields. However, Alloc deprotection with $\mathrm{Pd}\left(\mathrm{PPh}_{3}\right)_{4} /$ pyrrolidine led to poor recovery due to the highly polar nature of the deprotected product, which bound irreversibly to silica during purification by column chromatography. The problem could not be circumvented by use of the crude material in the subsequent step, owing to the sensitivity of the maleimide moiety to palladium and pyrrolidine.
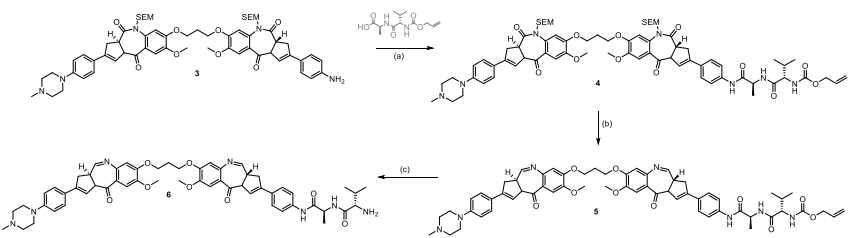

Scheme 2. Coupling sequence using Alloc-Val-Ala-OH: (a) EEDQ, $\quad \mathrm{CH}_{2} \mathrm{Cl}_{2} ; \quad$ (b) Super-Hydride ${ }^{\circledR}, \quad \mathrm{CH}_{2} \mathrm{Cl}_{2}$ then $\mathrm{CH}_{3} \mathrm{CN} / \mathrm{H}_{2} \mathrm{O}+0.1 \%$ formic acid; (c) Pyrrolidine, $\mathrm{Pd}\left(\mathrm{PPh}_{3}\right)_{4}$, $\mathrm{CH}_{2} \mathrm{Cl}_{2}$. 


\begin{tabular}{|c|c|c|c|c|}
\hline $\begin{array}{l}\text { Coupling } \\
\text { agent }\end{array}$ & Solvent & $\begin{array}{l}S^{a} \\
(\%)\end{array}$ & $\begin{array}{l}\text { Epimeri } \\
\text { sed } \\
\text { product }^{\mathrm{a}} \\
(\%)\end{array}$ & $\begin{array}{c}\text { Desired } \\
\text { product }^{\mathrm{a}} \\
(\%)\end{array}$ \\
\hline EEDQ & $\mathrm{CH}_{2} \mathrm{Cl}_{2}$ & 0 & 14 & 86 \\
\hline EEDQ & $\begin{array}{c}\mathrm{CH}_{2} \mathrm{Cl}_{2} / \\
\mathrm{MeOH} \\
100: 1\end{array}$ & 41 & 16 & 43 \\
\hline DCC & $\mathrm{CH}_{2} \mathrm{Cl}_{2}$ & 64 & 11 & 25 \\
\hline DCC/DMAP & $\mathrm{CH}_{2} \mathrm{Cl}_{2}$ & 51 & 26 & 23 \\
\hline DIC & $\mathrm{CH}_{2} \mathrm{Cl}_{2}$ & 56 & 17 & 27 \\
\hline DIC/Oxyma & $\mathrm{CH}_{2} \mathrm{Cl}_{2}$ & 0 & 44 & 56 \\
\hline HBTU/HOBt & $\mathrm{CH}_{2} \mathrm{Cl}_{2}$ & 57 & 6 & 37 \\
\hline HBTU/HOBt & DMF & 20 & 40 & 40 \\
\hline HATU & $\mathrm{CH}_{2} \mathrm{Cl}_{2}$ & 0 & 0 & 100 \\
\hline HATU/HOBt & $\mathrm{CH}_{2} \mathrm{Cl}_{2}$ & 36 & 0 & 64 \\
\hline HATU/HOBt & DMF & 6 & 36 & 58 \\
\hline
\end{tabular}

Fmoc was chosen as an alternative protecting group, since the conditions employed in the final deprotection with piperidine would allow for the use of free amine 9 to be used without purification in the next step. Applying coupling conditions similar to those previously mentioned, the coupling of Fmoc-Val-Ala-OH with EEDQ was successful (Scheme 3). However, upon LC/MS analysis, the chromatogram revealed a second peak $(13 \%$, Fig. (2)) with a mass identical to that of the desired product. Epimerisation of the chiral centre on the activated amino acid during coupling reactions is a common problem[16] and we therefore hypothesised that the racemisation of the $L$-alanine centre might have occurred to produce a diastereoisomeric mixture of products.

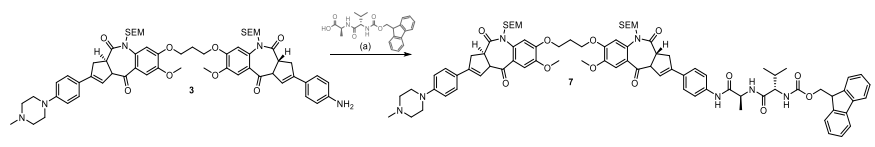

Scheme 3. Peptide coupling using Fmoc-Val-Ala-OH: (a) EEDQ, $\mathrm{CH}_{2} \mathrm{Cl}_{2}$.

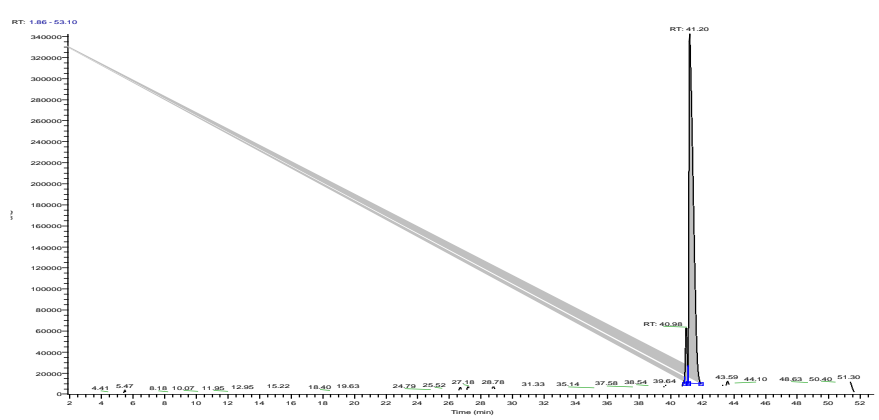

Fig. (2). LC/MS chromatogram displaying two peaks for the epimerised product.

Following these observations, we proceeded to screen multiple coupling conditions in order to find the most efficient, non-racemising method. It is important to note that these conditions were screened on the $N$-Me-piperazine intermediate (3, Table 2).

Table 2: Conditions tested to achieve non-racemising peptide coupling.

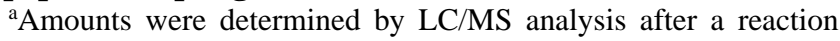
time of $2.5 \mathrm{~h}$

Nearly all the coupling conditions studied displayed various levels of epimerisation at the alanine chiral center. Both reactions using DCC and DIC proved to be very slow. Oxyma is as an efficient additive for peptide synthesis[17], known for its remarkable capacity to inhibit racemisation. However in our case, despite increasing the reaction rate, it produced almost equal amounts of the epimers. Reactions employing HBTU/HOBt were both very slow. Interestingly, there was a significant difference in epimerisation levels observed depending on whether the reaction was run in $\mathrm{CH}_{2} \mathrm{Cl}_{2}$ or DMF. Similarly, the reaction using HATU/HOBt in DMF displayed high levels of racemisation, whereas similar conditions in $\mathrm{CH}_{2} \mathrm{Cl}_{2}$ afforded the product as a single enantiomer. Finally, equimolar amounts of HATU/Fmoc-Val-Ala-OH in $\mathrm{CH}_{2} \mathrm{Cl}_{2}$ proved to be the most efficient conditions, affording product 7 in $76 \%$ yield and as a single diastereomer by LC/MS.

Subsequent reduction/deprotection of the SEM-dilactam 7 gave the corresponding imine 8. Fmoc deprotection using catalytic piperidine in DMF was complete within 10 minutes and after work up, product 9 was used in the next step without purification. Coupling of the acid spacer maleimide was achieved using EDCI.HCl and the final product was purified by reverse phase preparative HPLC to give pure payload SG3259 (Scheme 4).

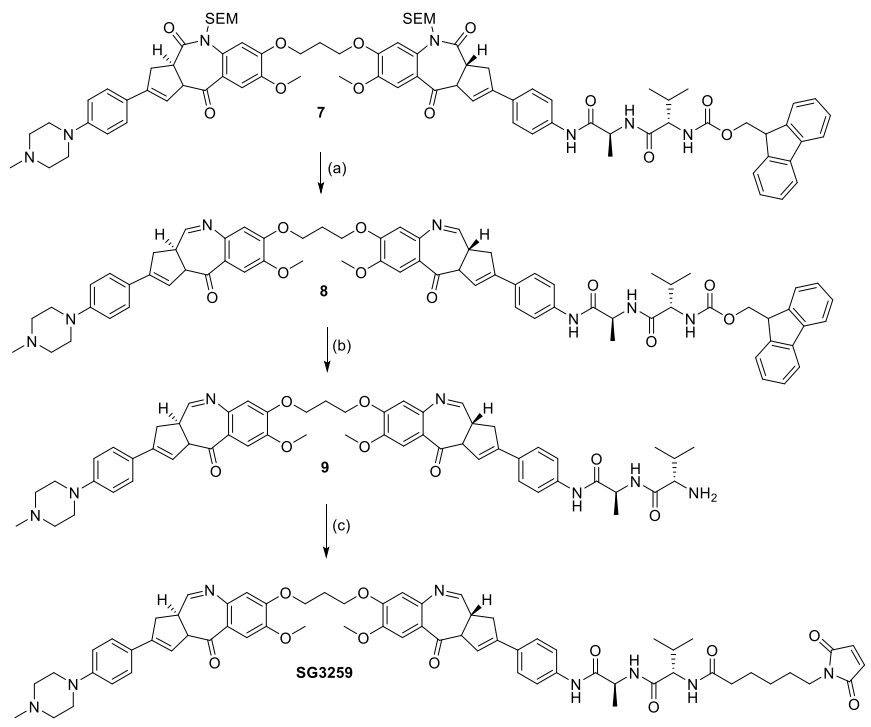

Scheme 4. Synthesis of piprazolirine SG3259: (a) SuperHydride ${ }^{\circledR}, \mathrm{CH}_{2} \mathrm{Cl}_{2}$ then $\mathrm{CH}_{3} \mathrm{CN} / \mathrm{H}_{2} \mathrm{O}+0.1 \%$ formic acid; (b) Piperidine, DMF; (c) maleimide caproic acid, EDCI.HCl, $\mathrm{CH}_{2} \mathrm{Cl}_{2}$.

Applying a similar set of conditions, diastereoisomer 10 was synthesised using Fmoc- $L$ Val-DAla-OH and as expected the product's peak had an identical retention time with that of the epimerised peak in the previous EEDQ coupling 
chromatogram. Subsequent reactions following the same route as described previously gave final product SG3664 in $27 \%$ yield and $95 \%$ purity (Scheme 5).
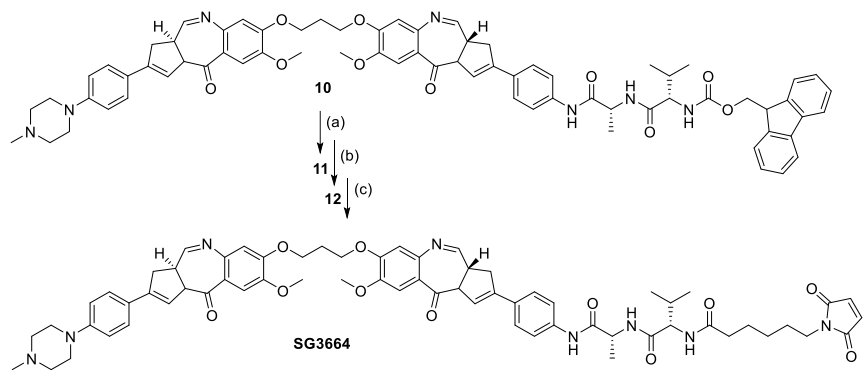

Scheme 5. Synthesis of diastereoisomer SG3664: (a) SuperHydride ${ }^{\circledR}, \mathrm{CH}_{2} \mathrm{Cl}_{2},-78^{\circ} \mathrm{C}$ then $\mathrm{MeOH} / \mathrm{CH}_{2} \mathrm{Cl}_{2} / \mathrm{H}_{2} \mathrm{O}$, silica gel, r.t. for 5 days; (b) Piperidine, DMF; (c) maleimide caproic acid, EDCI. $\mathrm{HCl}, \mathrm{CH}_{2} \mathrm{Cl}_{2}$.

\subsection{Warhead in vitro testing.}

The warheads, SG3132 and SG3312, were tested in Her2positive expressing cell lines and we were pleased to see that the activity/potency had been maintained if not improved in some cases (Table 3, Graph 1).

Table 3: $\mathrm{IC}_{50}$ values in various Her2-positive expressing cell lines.

\begin{tabular}{cccc}
\hline & \multicolumn{3}{c}{ IC $_{\mathbf{5 0}}(\mathbf{p M})$} \\
\hline Warhead & SK-OV-3 & NCI-N87 & SK-BR-3 \\
\hline SG3132 & 150 & 10 & 789 \\
SG3312 & 70 & 8.6 & 789 \\
\hline
\end{tabular}

Interestingly, SG3312 maintained potent cytotoxicity in $\mathrm{MDR}^{+}$cell lines with $\mathrm{P}$-glycoprotein (P-gp) overexpression (SK-OV-3, Table 4). These efflux pumps constitute one of the common mechanisms that lead to multidrug resistant (MDR) tumours. Increased expression of efflux pumps over time allows for the transport of small molecules (i.e. warheads) out of the cells, reducing their effectiveness. The results observed for our warhead is in line with those reported by several studies where positively ionisable groups (i.e. $N$-methylpiperazine) can enhance P-gp resistance[18, 19]. Indeed, we observe no difference in activity for $\mathbf{S G 3 3 1 2}$ whether Varapamil (a P-gp inhibitor) was used or not, suggesting that the PBD warhead is not a substrate for P-gp pumps.

Table 4. Effect of P-gp pumps on in vitro activity of PBD warheads.

\begin{tabular}{|c|c|c|c|c|}
\hline Warhead & $\begin{array}{c}\text { SK-OV- } \\
\text { 3-TR } \\
\text { (IC50 in } \\
\text { nM) }\end{array}$ & $\begin{array}{c}\text { SK-OV-3- } \\
\text { TR+VP } \\
\text { (IC50 in } \\
\text { nM) }\end{array}$ & $\begin{array}{c}\text { SK- } \\
\text { OV-3 } \\
\text { (IC50 } \\
\text { in nM) }\end{array}$ & $\begin{array}{l}\text { Resistance } \\
\text { Index } \\
\text { (fold- } \\
\text { change) }\end{array}$ \\
\hline SG3132 & 0.57 & 0.07 & 0.15 & 4 \\
\hline SG3312 & 0.05 & 0.03 & 0.07 & 1 \\
\hline MMAE & 0.07 & 14.67 & 0.5 & 209 \\
\hline
\end{tabular}

${ }^{\mathrm{a}} \mathrm{RI}=\mathrm{IC}_{50}$ for SK-OV-3-TR/IC50 for SK-OV-3. VP = Verapamil

\subsection{Conjugation and ADC testing in vitro and in vivo.}

Each diastereoisomer (SG3259 and SG3664) was efficiently conjugated to our proprietary I239-cysteine engineered Her2 monoclonal antibody (Herceptin-maia)[20] and compared both in vitro and in vivo with that of SG3211 (Table 5). Unlike SG3211, the conjugation of our new payloads did not necessitate the use of additional propylene glycol to increase their solubility and facilitate the reaction with the antibody. All three ADCs were isolated with similar yields and high monomeric purity. However, a more efficient conjugation was obtained with the piprazolirine payloads, giving a DAR of 1.89 versus 1.81 for $\mathbf{S G 3 2 1 1 . ~}$

Table 5. Conjugation data for the new payloads and comparison with SG3211.

\begin{tabular}{|c|c|c|c|c|}
\hline Description & $\begin{array}{c}\% \\
\text { Propylene } \\
\text { glycol }\end{array}$ & DAR & $\begin{array}{c}\% \\
\text { Monomer }\end{array}$ & $\begin{array}{c}\text { Yield } \\
(\%)\end{array}$ \\
\hline $\begin{array}{l}\text { Herceptin- } \\
\text { maia- } \\
\text { SG3211 }\end{array}$ & 33 & $\begin{array}{l}1.81 \\
(\mathrm{RP})\end{array}$ & 98 & 77 \\
\hline $\begin{array}{l}\text { Herceptin- } \\
\text { maia- } \\
\text { SG3259 }\end{array}$ & 0 & $\begin{array}{l}1.89 \\
\text { (RP) }\end{array}$ & 98 & 73 \\
\hline $\begin{array}{l}\text { Herceptin- } \\
\text { maia- } \\
\text { SG3664 }\end{array}$ & 0 & $\begin{array}{l}1.89 \\
\text { (RP) }\end{array}$ & 98 & 78 \\
\hline
\end{tabular}

Following conjugation, the ADCs efficacy were assayed in vitro in the high Her2 ${ }^{+++}$expressing NCI-N87 (Table 6). Pleasingly, the ADC bearing SG3259 was over 10 times more efficacious than that of SG3211.

Table 6: In vivo data in $\mathrm{Her}^{+++}$cell lines. NCI-N87 GI50 (nM/mL)

$\begin{array}{ll}\text { Her-maia-SG3211 } & 0.71 \\ \text { Her-maia-SG3259 } & 0.05 \\ \text { Her-maia-SG3664 } & 6.87\end{array}$




\section{NCI-N87}

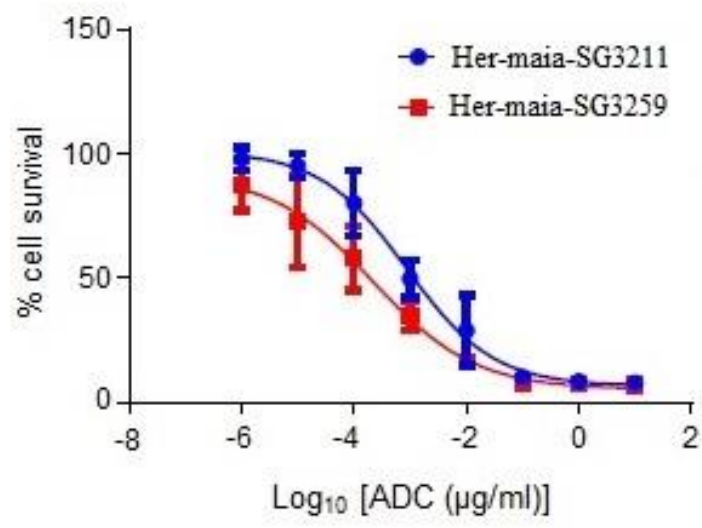

\begin{tabular}{|c|c|}
\hline & $\mathrm{EC}_{50}$ \\
\hline Her-maia-SG3211 & 0.000867 \\
Her-maia-SG3259 & 0.000219 \\
\hline
\end{tabular}

Graph 1. In vitro testing of ADCs in NCI-N87.

As expected, the ADC of diastereomer SG3664 was less potent (140x) than that of SG3259, suggesting that the warhead had not been released by cleavage to the same extent. Further protease activity assay confirmed that the SG3664 conjugate with the non-natural dipeptide $L$-Val- $D$ Ala was not cleaved in the presence of natural human cathepsin B protein (Graph 2). Although this result was to be expected, the nM activity of Her-maia-SG3664 suggests that either a non-enzymatic process is involved in releasing the warhead from its dipeptide trigger, or that the cysteine metabolite released after antibody degradation also has some activity.

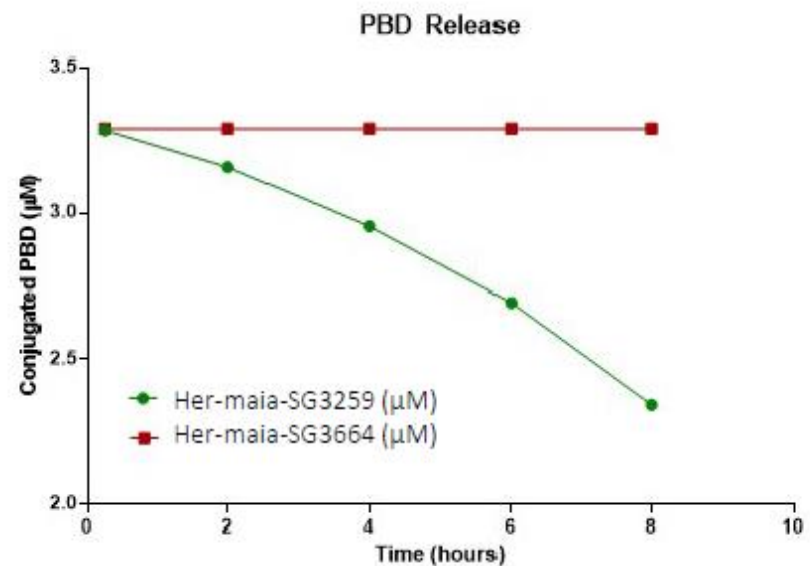

Graph 2. Cathepsin B cleavage of SG3259 and SG3664 overtime.

An in vivo study was conducted in the Her2 $2^{++/+}$JIMT-1 xenograft model[21], a cell line with low expression of the Her $/$ neu protein, revealing that treatment with high doses (1 $\mathrm{mg} / \mathrm{kg}$, iv, qdx1) of both ADC-SG3211 and ADC-SG3259 leads to significant tumor regression. Treatment with a lower dose $(0.3 \mathrm{mg} / \mathrm{kg}$, iv, qdx1) showed homeostasis in the case of ADC-SG3211, whereas ADC-SG3259 displayed sustained tumor regression (Graph 3).

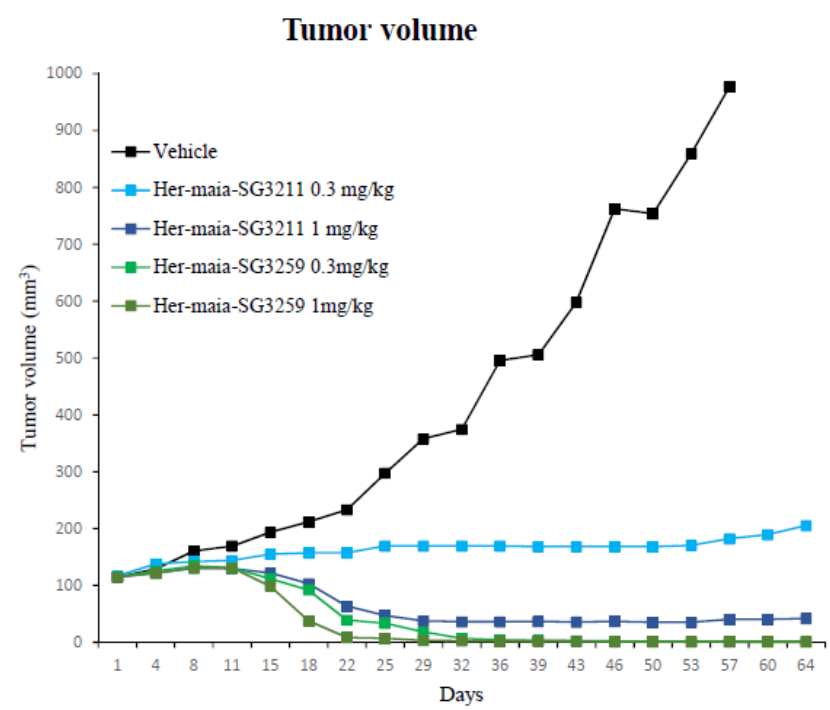

Graph 3. ADC activity in Her2 ++/+ JIMT-1 breast xenograft model.

\section{CONCLUSION}

We have successfully designed and synthesized a novel PBD warhead (SG3312) with enhanced physico-chemical properties. The warhead also displayed increased potency in vitro. After overcoming some epimerization issues, the synthesis of enantiomerically pure payload was achieved (SG3259) and fulfilled our criteria for a simplified and more efficient conjugation: no addition of propylene glycol required, high DAR and excellent monomeric purity.

The ADC (Herceptin-maia-SG3259) has been shown to release the active warhead (SG3312) upon exposure to Cathepsin B and demonstrated encouraging activity both in vitro and in vivo.

\section{LIST OF ABBREVIATIONS}

${ }^{\circ} \mathrm{C}$ : Degree Celsius

DAR: Drug Antibody Ratio

DCC: N,N'-Dicyclohexylcarbodiimide

DIC: N,N'-Diisopropylcarbodiimide

DMAP: Dimethylaminopyridine

DMF: Dimethylformamide

DNA: Deoxyribonucleic acid

EDCI: 1-Ethyl-3-(3-dimethylaminopropyl)carbodiimide

EEDQ: N-Ethoxycarbonyl-2-ethoxy-1,2-dihydroquinoline

ES: Electrospray

EtOAc: Ethyl acetate

$\mathrm{GI}_{50}: 50 \%$ Growth Inhibition

HATU: 1-[Bis(dimethylamino)methylene]-1H-1,2,3triazolo[4,5-b]pyridinium 3-oxide hexafluorophosphate

HBTU: Hexafluorophosphate Benzotriazole Tetramethyl Uronium

HOBt: Hydroxybenzotriazole

HPLC: High Pressure Liquid Chromatography

$\mathrm{IC}_{50}$ : Half maximal inhibitory concentration

LC/MS: Liquid Chromatography Mass Spectrometry

mAb: Monoclonal antibody

$\mathrm{MeOH}$ : Methanol

Min: minute 
MMAE: Monomethyl auristatin E

P-gp: P-glycoprotein

r.t.: Retention Time

SEM: 2-(Trimethylsilyl)ethoxymethyl

THF: Tetrahydrofurane

\section{REFERENCES}

1. Dan, N., et al., Antibody-Drug Conjugates for Cancer Therapy: Chemistry to Clinical Implications. Pharmaceuticals, 2018. 11(2): p. 32.

2. Joseph A. Francisco, C.G.C., Damon L. Meyer, Bruce J. Mixan, Kerry Klussman, Dana F. Chace, Starr X. Rejniak, Kristine A. Gordon, Ron DeBlanc, Brian E. Toki, Che-Leung Law, Svetlana O. Doronina, Clay B. Siegall, Peter D. Senter and Alan F. Wahl, cAC10-vcMMAE, an anti-CD30monomethyl auristatin $E$ conjugate with potent and selective antitumor activity. Blood, 2003. 102(4): p. 8.

3. Lewis Phillips, G.D., et al., Targeting HER2Positive Breast Cancer with Trastuzumab-DM1, an Antibody-Cytotoxic Drug Conjugate. Cancer Research, 2008. 68(22): p. 9280-9290.

4. DiJoseph, J.F., et al., Antibody-targeted chemotherapy with CMC-544: a CD22-targeted immunoconjugate of calicheamicin for the treatment of B-lymphoid malignancies. Blood, 2004. 103(5): p. 1807-1814.

5. Hamann, P.R., et al., Gemtuzumab Ozogamicin, A Potent and Selective Anti-CD33 Antibody-Calicheamicin Conjugate for Treatment of Acute Myeloid Leukemia. Bioconjugate Chemistry, 2002. 13(1): p. 47-58.

6. Leimgruber, W., et al., Isolation and Characterization of Anthramycin, a New Antitumor Antibiotic. Journal of the American Chemical Society, 1965. 87(24): p. 5791-5793.

7. Hartley, J.A., et al., SG2285, a Novel C2-ArylSubstituted Pyrrolobenzodiazepine Dimer Prodrug That Cross-links DNA and Exerts Highly Potent Antitumor Activity. Cancer Research. 70(17): p. 6849-6858.

8. Bose, D.S., et al., Rational design of a highly efficient irreversible DNA interstrand cross-linking agent based on the pyrrolobenzodiazepine ring system. Journal of the American Chemical Society, 1992. 114(12): p. 4939-4941.

9. Tiberghien, A.C., et al., Design and Synthesis of Tesirine, a Clinical Antibody-Drug Conjugate Pyrrolobenzodiazepine Dimer Payload. ACS Medicinal Chemistry Letters, 2016. 7(11): p. 983987.

10. Zammarchi, F., et al., ADCT-402, a PBD dimercontaining antibody drug conjugate targeting CD19-expressing malignancies. Blood, 2018. 131(10): p. 1094-1105.

11. Jeffrey, S.C., et al., A Potent Anti-CD70 AntibodyDrug Conjugate Combining a Dimeric Pyrrolobenzodiazepine Drug with Site-Specific
Conjugation Technology. Bioconjugate Chemistry, 2013. 24(7): p. 1256-1263.

12. Kung Sutherland, M.S., et al., SGN-CD33A: a novel CD33-targeting antibody-drug conjugate using a pyrrolobenzodiazepine dimer is active in models of drug-resistant AML. Blood, 2013. 122(8): p. 14551463.

13. MarvinSketch. Marvin was used for drawing, displaying and characterizing chemical structures, substructures and reactions, Marvin 14.7.7.0, 2014, ChemAxon (http://www.chemaxon.com).

14. Jeffrey, S.C., et al., Dipeptide-based highly potent doxorubicin antibody conjugates. Bioorganic \& Medicinal Chemistry Letters, 2006. 16(2): p. 358362.

15. Howard, P.W., et al., Synthesis of a novel C2/C2'aryl-substituted pyrrolo[2,1-c][1,4]benzodiazepine dimer prodrug with improved water solubility and reduced DNA reaction rate. Bioorganic \& Medicinal Chemistry Letters, 2009. 19(22): p. 6463-6466.

16. Grahl-Nielsen, O., Racemisation in peptide synthesis. Journal of the Chemical Society D: Chemical Communications, 1971(24): p. 15881589.

17. Subirós-Funosas, R., et al., Oxyma: An Efficient Additive for Peptide Synthesis to Replace the Benzotriazole-Based HOBt and HOAt with a Lower Risk of Explosion[1]. Chemistry - A European Journal, 2009. 15(37): p. 9394-9403.

18. Chen, L., et al., Computational models for predicting substrates or inhibitors of $P$ glycoprotein. Drug Discovery Today. 17(7â€"8): p. 343-351.

19. Di, E.H.K.a.L., Drug-like properties: concepts, structure design and methods from ADME to toxocity optimization. 2008.

20. Dimasi, N., et al., Efficient Preparation of SiteSpecific Antibody-Drug Conjugates Using Cysteine Insertion. Molecular Pharmaceutics, 2017. 14(5): p. 1501-1516.

21. Tanner, M., et al., Characterization of a novel cell line established from a patient with Herceptinresistant breast cancer. Molecular Cancer Therapeutics, 2004. 3(12): p. 1585-1592. 